\title{
A fuzzy logic controller based brushless DC motor using PFC cuk converter
}

Sanatan Kumar, Debanjan Roy, Madhu Singh

Departement of Electrical Engineering, National Institute of Technology, India

\begin{tabular}{|c|c|}
\hline Article Info & ABSTRACT \\
\hline $\begin{array}{l}\text { Keywords: } \\
\text { Brushless DC Motor (BLDC) } \\
\text { CUK Converter } \\
\text { Continuous Current Mode } \\
\text { (CCM) } \\
\text { Discontinuous Current Mode } \\
\text { (DCM) } \\
\text { Fuzzy Logic Controller (FLC) } \\
\text { Power Factor Correction (PFC) } \\
\end{array}$ & $\begin{array}{l}\text { This paper presents a PFC (Power Factor Correction) Cuk converter fed } \\
\text { BLDC (Brushless DC) motor drive and the speed of BLDC motor is } \\
\text { controlled using fuzzy logic implementation. The PFC converters are } \\
\text { employed to enhance the power quality. The Brushless DC motor speed is } \\
\text { under the control of DC-bus voltage of VSI-Voltage Source Inverter in which } \\
\text { switching of low frequency is used. This helps in the electronic commutation } \\
\text { of BLDC motors thus decreasing the switching losses in VSI. A DBR (Diode } \\
\text { Bridge Rectifier) next to the PFC Cuk converter controls the voltage at DC } \\
\text { link maintaining unity power factor. The characteristics of Cuk converter in } \\
\text { four dissimilar mo des of operation are studied such as continuous and } \\
\text { discontinuous conduction modes (CCM and DCM) respectively. The } \\
\text { entire system is simulated using Matlab/Simulink software and the } \\
\text { simulation results are reported to verify the performance investigation of the } \\
\text { proposed system. } \\
\text { Copyright (C) } 2019 \text { Institute of Advanced Engineering and Science. } \\
\text { All rights reserved. }\end{array}$ \\
\hline \multicolumn{2}{|l|}{ Corresponding Author: } \\
\hline \multicolumn{2}{|c|}{$\begin{array}{l}\text { Sanatan Kumar, } \\
\text { Departement of Electrical Engineering, } \\
\text { National Institute of Technology, } \\
\text { Jamshedpur, Jharkhand-831014, India. } \\
\text { Email: 2015rsee001@nitjsr.ac.in }\end{array}$} \\
\hline
\end{tabular}

\section{INTRODUCTION}

Brushless DC motors are most efficient motors gaining importance because of power quality enhancements. These motors possess high reliability, high efficiency, high ruggedness, high power density, low EMI difficulties [1-3]. They are appropriate for medium and low power applications such as household equipment, medical equipment, industrial tools, heating, ventilating and air conditioning (HVAC) [4]. BLDC motor is a synchronous motor in which three phase windings are present on the stator whereas on the rotor there will be permanent magnets. The Hall Effect sensors sense the position of the rotor for electronic commutation of the motor. This commutation is according to the switching table having six switches of VSIVoltage Source Inverter that are turned ON and OFF based on the current rotor position. Thus the problems caused by conventional DC motors like noise, sparking, EMI-Electromagnetic Interface etc. can be eliminated by this commutation [5-6].

Conventionally, BLDC motor is served by a Diode Bridge Rectifier-DBR and a high value DC link capacitor, drawing high currents with high distortions form AC mains supply [7]. Such current has reduced power factor i.e., as low as 0.7 , high amount of harmonics resulting high THD (Total Harmonic Distortion) i.e., as high as $65 \%$ at $\mathrm{AC}$ mains, which are not under the limits mentioned in International Standard of Power Quality IEC 61000-3-2. Therefore a single phase PFC (power factor correction) converters are utilized for power quality improvement at AC mains. Literature [8] reports the configurations of power conversion at single stage with isolation and without isolation.

Different configurations of power factor corrected converter based BLDC motors have been mentioned in literature. A PFC boost converter serving BLDC motor drive is reported in $[9,10]$, which PWM 
(Pulse Width Modulation) based VSI control is used for speed control. But the high switching frequency of PWM pulses cause high losses of switching. The techniques used for feeding BLDC also cause high losses in switching. Thus DC link voltage concept has risen for reducing these losses [11]. In this VSI is used for the operation in switching at low frequency. Bridgeless configuration of PFC buck-boost converter, Cuk converter, SEPIC converter and Zeta converter are proposed in [12-13] respectively. These reduce losses but more number of active as well as passive components is required thus increasing cost.

The optimum level of performance from BLDC motor might be achieved by the use of suitable speed controllers. Several controllers like proportional integral (PI), Fuzzy logic controller (FLC) and Neural Network (NN) are offered for speed control of such electrical drives system [14]. The PI controller is mainly used due to its effortless control structure and ease of implementation. These controllers at the same time pose several difficulties such as control complication, nonlinearity, load disturbances, parametric variations and time delayed system [15].

For faster dynamic response Fuzzy logic controller or in combination with PI is frequently accessed controller for the speed control of a BLDC motor drive. Application of fuzzy logic in favor of a power factor correction converter can yield improvements due to it's enhance performance of the system and can offer good responses throughout the variations of load or output voltage reference value. There are numerous works that use fuzzy logic for APFC, but these works apply a high number of rules, which will exhibit an additional cost and decrease the rapidity of devices. Thus, in this work, we try using FLC with a small number of rules compared to previous works.

The choice of operating mode at front end converter is an important criterion in order to adjust the stress allowed on PFC and at the same time maintaining the cost. The PFC converters are operated in continuous and discontinuous conduction modes CCM and DCM respectively. In CCM, a current multiplier approach is employed for PFC converter with less stress on converter switch but three sensors are needed. These are used in medium and high power applications. Whereas in DCM, voltage follower method is employed with high stress on converter switch and is used in low power applications. Based on the design parameters the converter operates in either CCM or DCM. In this paper, four operation modes are investigated for PFC Cuk converter with BLDC motor for operating over high speed range maintaining unity $\mathrm{PF}$ near AC mains. The different operation modes are CCM using current multiplier technique and three DCM methods using voltage follower method.

\section{SYSTEM DESIGN}

Figure 1 and Figure 2 depicts a BLDC (Brushless DC) machine drive is fed by a PFC (Power Factor Correction) Cuk converter using two methods such as current multiplier and voltage follower methods. The high frequency MOSFET and in cuk converter and IGBTs with low frequency of operation has been used in VSI (Voltage Source Inverter) to control the power factor and voltage. The switching mode of fundamental frequency for IGBTs is achieved because of electronic commutation of BLDC machine. This in turn causes reduction in switching losses.

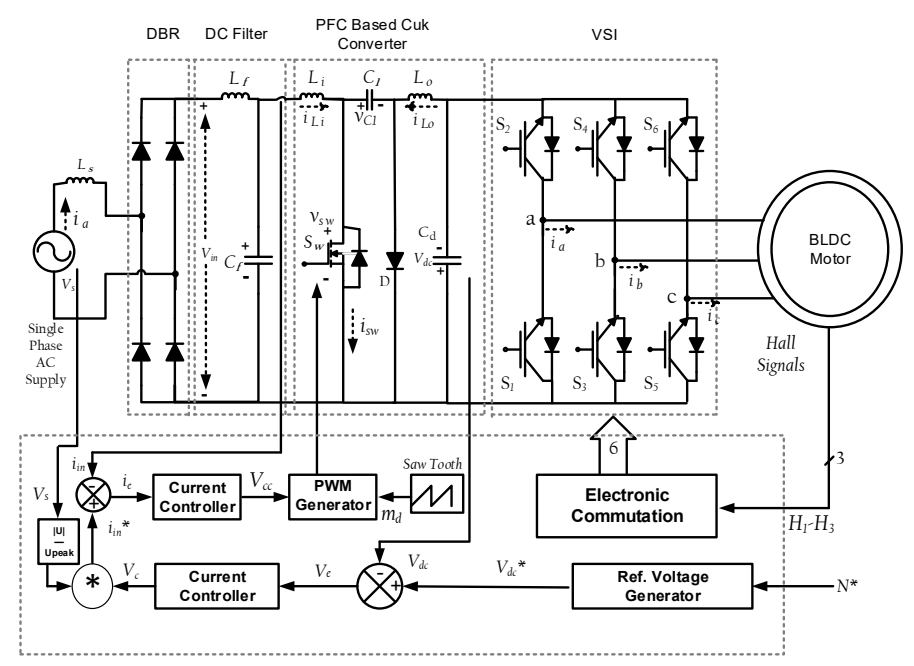

Figure 1. Brushless DC machine drive fed by a PFC Cuk converter with current multiplier technique 
In Figure 1, where PFC Cuk converter works in CCM, the current through the inductors $\left(\mathrm{L}_{2}\right.$ and $\left.\mathrm{L}_{1}\right)$ and voltage across capacitor $\left(\mathrm{C}_{1}\right)$ stay continuous during switching period, whereas in Figure 2, where the Cuk converter functions in DCM, the current through either of the inductors $\left(\mathrm{L}_{2}\right.$ and $\left.\mathrm{L}_{1}\right)$ or voltage across capacitor $\left(\mathrm{C}_{1}\right)$ turn into discontinuous mode during switching period. Here four conduction modes are considered for Cuk converter i.e., three discontinuous and a continuous conduction mode whose performance is estimated maintaining unity power factor near AC mains.

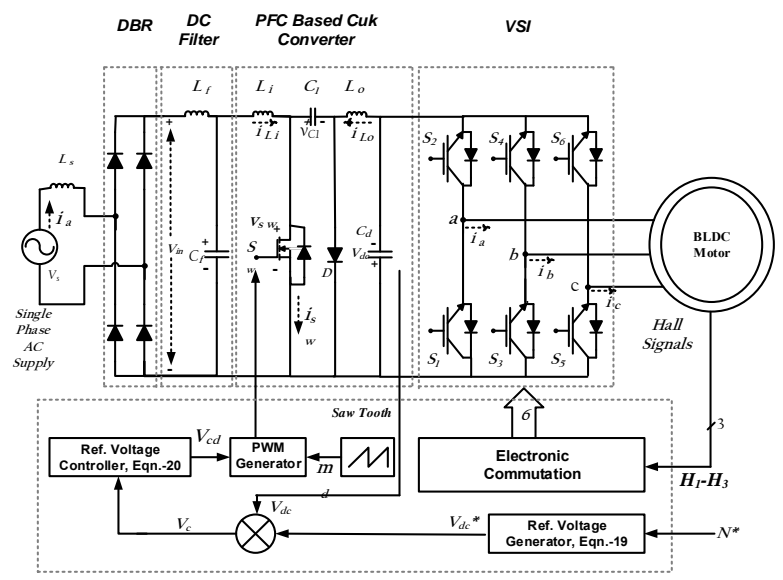

Figure 2. Brushless DC machine drive fed by a PFC Cuk converter with voltage follower method

\section{OPERATION MODE OF CUK CONVERTER}

The Cuk converter works in four various modes of continuous conduction mode (CCM) and discontinuous conduction mode (DCM). The DCM is again divided into two more categories such as Discontinuous Inductor Current Mode (DICM) and Discontinuous Capacitor Voltage Mode (DCVM). In $\mathrm{CCM}$, there is a continuous flow of current through inductors $\left(\mathrm{L}_{1}\right.$ and $\left.\mathrm{L}_{2}\right)$ and voltage through intermediate capacitor $\left(\mathrm{C}_{1}\right)$ respectively in switching period. In DCIM, the current through either input inductor $\left(\mathrm{L}_{1}\right)$ or output inductor $\left(\mathrm{L}_{2}\right)$ become discontinuous based on their respective operation modes and in DCVM, voltage across capacitor $\left(\mathrm{C}_{1}\right)$ turn out to be discontinuous during switching period. Different modes for operation and its performance are evaluated for wide voltage control with unity power factor are discussed as follows.

\subsection{CCM operation}

In this mode, the Cuk converter is operated in two intervals Interval I and Interval II of a switching period as shown in Figure 3(a) and (b) respectively, and Figure 3(c) displays the waveforms associated with entire switching period. During Interval $\mathrm{I}$, when switch $\left(\mathrm{S}_{\mathrm{W}}\right)$ is $\mathrm{ON}$, the input inductor $\mathrm{L}_{1}$ gets charged whereas the capacitor $C_{1}$ discharges energy and transfers to DC link capacitor $\left(C_{d}\right)$. Here the current through inductor $\mathrm{i}_{\mathrm{L} 1}$ increases while voltage across capacitor $\mathrm{V}_{\mathrm{C} 1}$ decreases. During Interval II, when the switch is $\mathrm{OFF}$, the inductor $\mathrm{L}_{1}$ discharges its energy and transfers to capacitor $\mathrm{C}_{1}$, whereas the de link capacitor gets energy from the output inductor $\mathrm{L}_{2}$.

\subsection{DICM $\left(\mathrm{L}_{1}\right)$ operation}

In DCIM, the Cuk converter operates in three various intervals of switching period which are depicted in Figure 4(a) to (c) and the waveforms are shown in Figure 4(d). During I interval, when switch is $\mathrm{ON}$, inductor $\mathrm{L}_{1}$ gets charged, capacitor $\mathrm{C}_{1}$ discharges energy and transfers to DC link capacitor via switch. Here current through inductor $\mathrm{L}_{1}, \mathrm{i}_{\mathrm{L} 1}$ increases whereas the voltage through capacitor $\mathrm{C}_{1}$ decreases. During II interval, the switch is OFF, inductor $\mathrm{L}_{1}$ handovers its stored energy to capacitor $\mathrm{C}_{1}$ through diode $\mathrm{D}$ till it is discharged completely. In III interval, as there is no energy in $L_{1}$, current $i_{L 1}$ equals zero and the inductor $L_{2}$ supplies energy to the DC link capacitor $\mathrm{C}_{\mathrm{d}}$ in continuous mode.

\subsection{DICM $\left(\mathrm{L}_{2}\right)$ operation}

Figure 5(a) to (c) depicts the Cuk converter operation in DICM in three intervals of switching period and the waveforms associated with them are shown in Figure 5(d). During I interval, the operation is same as 
in DICM $\left(\mathrm{L}_{1}\right)$ operation. In interval II, $\mathrm{L}_{1}$ and $\mathrm{L}_{2}$ transmit their stored energy to $\mathrm{C}_{1}$ and $\mathrm{C}_{\mathrm{d}}$ respectively. In III interval, inductor $\mathrm{L}_{2}$ is discharged completely i.e., until $\mathrm{iI}_{\mathrm{L} 2}$ equals 0 . The capacitor $\mathrm{C}_{1}$ gets energy from inductor $\mathrm{L}_{1}$ through diode in continuous mode. The parameters for all the modes of operation are given in Table 2. In this mode improved power quality operation is achieved for the entire range of speed control.

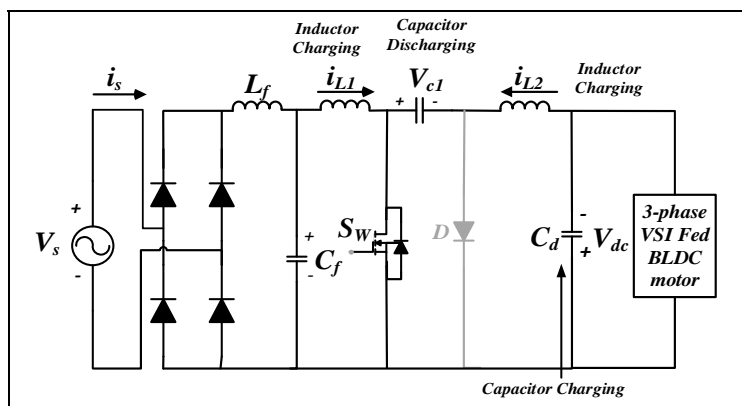

(a)

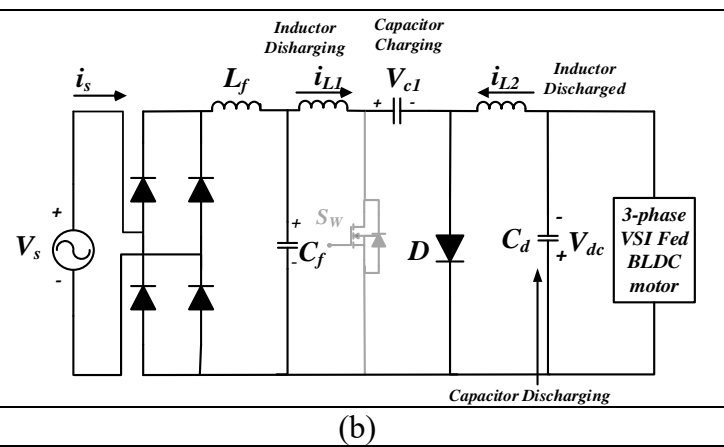

(b)

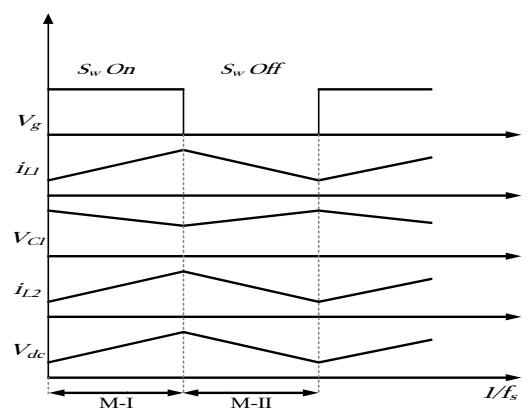

(c)

Figure 3. Cuk converter operation in CCM at (a-b) various instance of switching zone and (c) the resulting waveforms

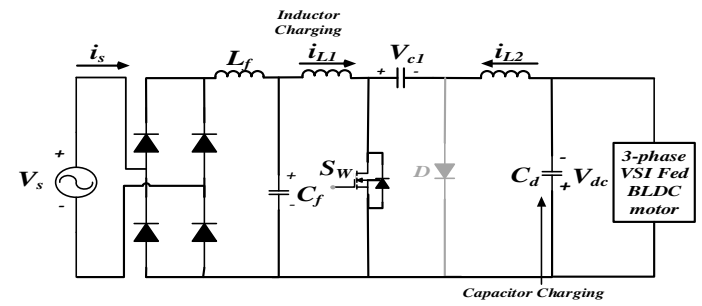

(a)

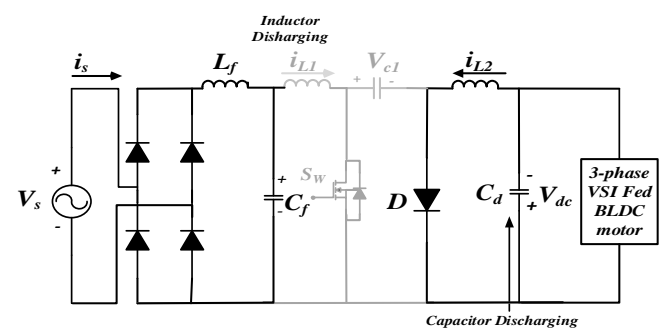

(c)

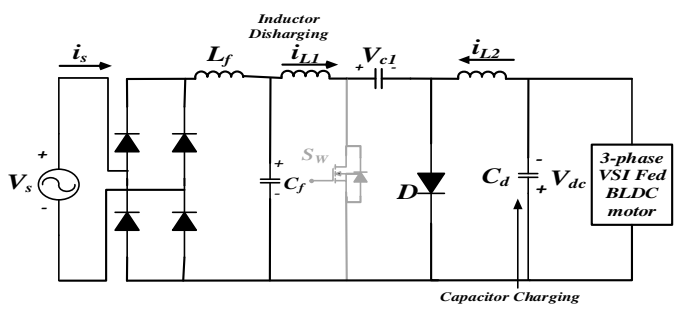

(b)

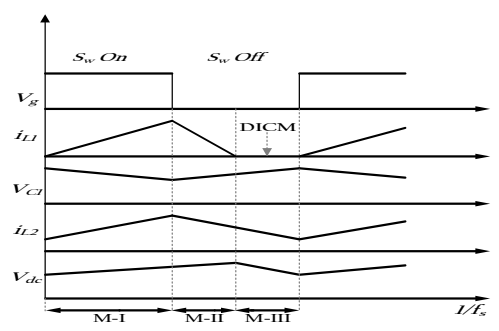

(d)

Figure 4. Cuk converter operation in $\operatorname{DICM}\left(\mathrm{L}_{1}\right)$ at (a-c) various instance of switching zone and (d) the resulting waveforms 


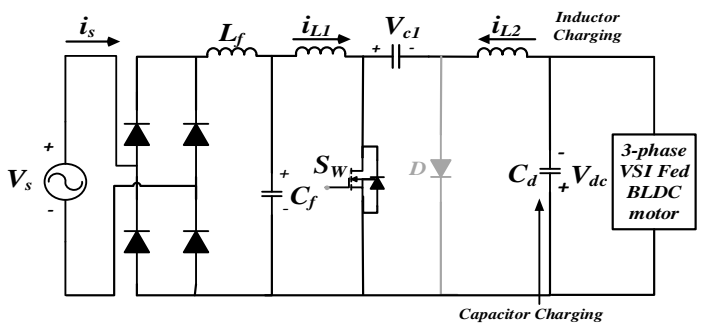

(a)

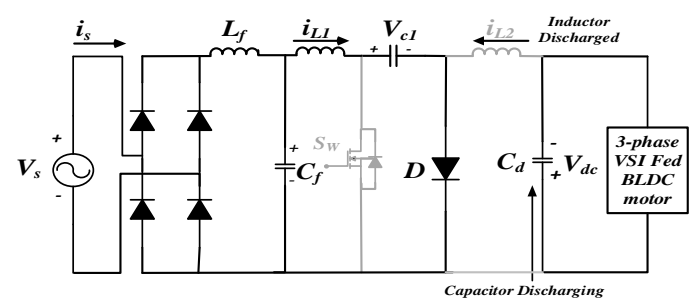

(c)

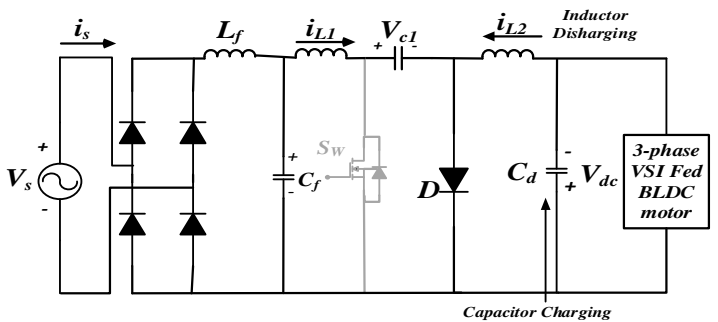

(b)

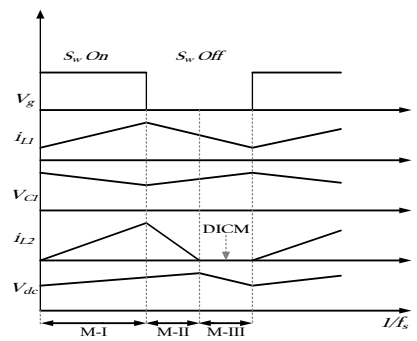

(d)

Figure 5. Cuk converter operation in DICM (L2) at (a-c) various instance of switching zone and (d) the resulting waveforms

\subsection{DCVM operation}

The Cuk converter functioning in DCVM $\left(\mathrm{C}_{1}\right)$ in three switching period intervals is shown in Figure 6(a) to (c) and associated waveforms are shown in Figure 6(d). During I interval the Cuk operation is same as in DICM $\left(\mathrm{L}_{1}\right)$ and DICM $\left(\mathrm{L}_{2}\right)$. In interval II, the switch is $\mathrm{ON}$ but as capacitor $\mathrm{C}_{1}$ gets discharged completely, the voltage across the capacitor becomes zero and inductor $\mathrm{L}_{2}$ transfers power to DC link capacitor. During III interval the switch is OFF, inductor $\mathrm{L}_{1}$ begins the charging of intermediate capacitor, whereas inductor $\mathrm{L}_{2}$ remains operating in continuous conduction supplying energy to DC link capacitor.

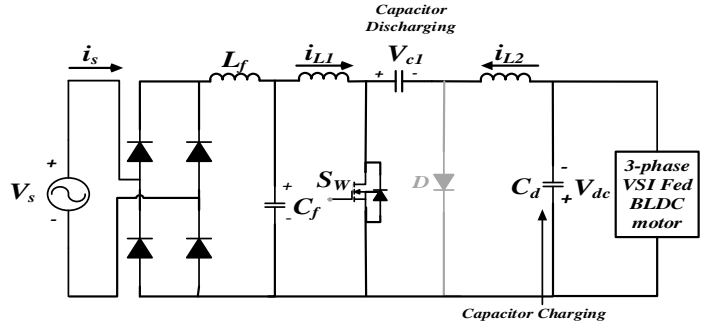

(a)

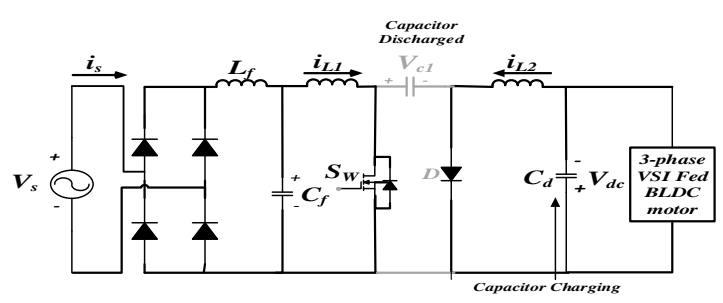

(c)

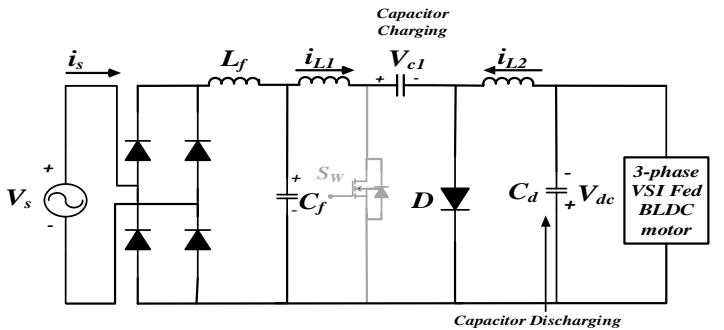

(b)

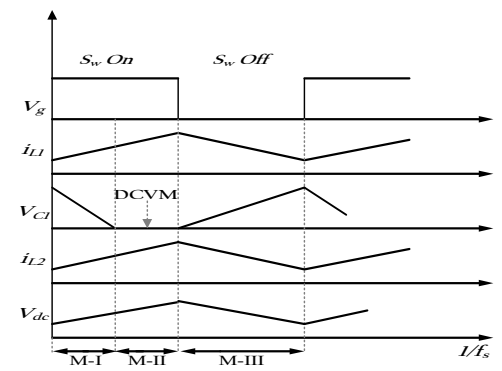

(d)

Figure 6. Cuk converter operation in $\operatorname{DCVM}\left(\mathrm{C}_{1}\right)$ at (a-c) various instance of switching zone and (d) the related waveforms

Int J Pow Elec \& Dri Syst Vol. 10, No. 4, Dec 2019 : 1894 - 1905 


\section{CONTROL TECHNIQUE}

The two control techniques used for the PFC Cuk converter are named as current multiplier method for and voltage follower technique for operating in CCM and DCM respectively. Conventionally PI controller is used as a classical control method and Fuzzy logic controller is modern control technique used for the enhancement the performance of motor drive as compression to classical method.

\subsection{Current multiplier technique}

Reference Voltage Generator generates the reference voltage-Vdc* which equivalent with respect to the reference speed-N*, because BLDC motor speed is proportional to voltage at DC link of the VSI. The Cuk converter with current multiplier scheme is shown in Figure 1. The formula for generating reference voltage is the product of the voltage constant $\mathrm{Kb}$ and the speed $\mathrm{N}^{*}$,

$$
\mathrm{V}_{\mathrm{dc}}^{*}=\mathrm{K}_{\mathrm{b}} \mathrm{N}^{*}
$$

The comparison of the Vdc* with Vdc i.e., the sensed DC link voltage produces a voltage error denoted as $\mathrm{Ve}$ and calculated at instant ' $\mathrm{K}$ ' by

$$
\mathrm{V}_{\mathrm{e}}(\mathrm{k})=\mathrm{V}_{\mathrm{dc}}^{*}(\mathrm{k})-\mathrm{V}_{\mathrm{dc}}(\mathrm{k})
$$

The voltage error then sent to PI controller and the controlled output $\mathrm{V}_{\mathrm{C}}$ is generated as,

$$
\mathrm{V}_{\mathrm{c}}(\mathrm{k})=\mathrm{V}_{\mathrm{c}}(\mathrm{k}-1)+\mathrm{k}_{\mathrm{pv}}\left\{\mathrm{V}_{\mathrm{e}}(\mathrm{k})-\mathrm{V}_{\mathrm{e}}(\mathrm{k}-1)\right\}+\mathrm{k}_{\mathrm{iv}} \mathrm{V}_{\mathrm{e}}(\mathrm{k})
$$

Here $\mathrm{k}_{\mathrm{pv}}$ and $\mathrm{k}_{\mathrm{iv}}$ denotes the proportional and the integral gains of voltage PI controller respectively. The multiplication of the controller output and the supply voltage unit template gives the reference current $\mathrm{i}_{\text {in }} *$ as,

$$
i_{\text {in }}^{*}(k)=\left|\frac{V_{s}(k)}{V_{m}}\right| V_{c}(k)
$$

Where $V_{s}(k) / V_{m}$ represents unit template of supply voltage, $V_{s}$ and $V_{m}$ indicates the supply voltage amplitude. The current error is generated when the reference current is matched with sensed input current, it is given as,

$$
\mathrm{i}_{\mathrm{e}}(\mathrm{k})=\mathrm{i}_{\text {in }}^{*}(\mathrm{k})-\mathrm{i}_{\text {in }}(\mathrm{k})
$$

This error is sent to the current controller that generates a controlled output $\left(\mathrm{V}_{\mathrm{cc}}\right)$ given as,

$$
\mathrm{V}_{\mathrm{cc}}(\mathrm{k})=\mathrm{V}_{\mathrm{cc}}(\mathrm{k}-1)+\mathrm{k}_{\mathrm{pi}}\left\{\mathrm{i}_{\mathrm{e}}(\mathrm{k})-\mathrm{i}_{\mathrm{e}}(\mathrm{k}-1)\right\}+\mathrm{k}_{\mathrm{ii}} \mathrm{i}_{\mathrm{e}}(\mathrm{k})
$$

Where, $\mathrm{k}_{\mathrm{pi}}$ and $\mathrm{k}_{\mathrm{ii}}$ represents the proportional gain and integral gain of the current PI controller. Finally, $\mathrm{V}_{\mathrm{cc}}$, the controller output, is compared with saw tooth waveform of high frequency in order to produce the PWM signal which is given to converter switch as,

$$
\mathrm{m}_{\mathrm{d}}(\mathrm{t})<\mathrm{V}_{\mathrm{cc}}(\mathrm{t}), \text { then } \mathrm{S}_{\mathrm{W}}=1 \text {, else } \mathrm{S}_{\mathrm{W}}=0
$$

Where, $\mathrm{S}_{\mathrm{w}}$ indicates the switching signals, 0 and 1 for MOSFET to switch OFF and ON respectively.

\subsection{Voltage follower method}

In this scheme, a reference voltage $\left(\mathrm{V}_{\mathrm{dc}}{ }^{*}\right)$ equivalent to the certain reference speed $\mathrm{N}^{*}$ is generated related to the current multiplier technique as,

$$
\mathrm{V}_{\mathrm{dc}}^{*}=\mathrm{K}_{\mathrm{b}} \mathrm{N}^{*}
$$


Where $\mathrm{kb}$ denotes the voltage constant and $\mathrm{N}^{*}$ represents reference speed. And this reference voltage $\mathrm{V}_{\mathrm{dc}}{ }^{*}$ is compared with $\mathrm{V}_{\mathrm{dc}}$, sensed DC link voltage generating a voltage error $\left(\mathrm{V}_{\mathrm{e}}\right)$ which is given as at instant ' $\mathrm{k}$ ' as,

$$
\mathrm{V}_{\mathrm{e}}(\mathrm{k})=\mathrm{V}_{\mathrm{dc}}^{*}(\mathrm{k})-\mathrm{V}_{\mathrm{dc}}(\mathrm{k})
$$

The PI controller then handles this error and generates controlled output (Vcd) given as,

$$
\mathrm{V}_{\mathrm{cd}}(\mathrm{k})=\mathrm{V}_{\mathrm{cd}}(\mathrm{k}-1)+\mathrm{k}_{\mathrm{pv}}\left\{\mathrm{V}_{\mathrm{e}}(\mathrm{k})-\mathrm{V}_{\mathrm{e}}(\mathrm{k}-1)\right\}+\mathrm{k}_{\mathrm{iv}} \mathrm{V}_{\mathrm{e}}(\mathrm{k})
$$

Where, $\mathrm{k}_{\mathrm{pv}}$ and $\mathrm{k}_{\mathrm{iv}}$ are the proportional and integral gains of the voltage PI controller.

Lastly $\mathrm{V}_{\mathrm{cc}}$, the controller output in comparison with saw tooth of high frequency waveform produces the PWM signal which is given to converter switch is follows,

$$
\mathrm{m}_{\mathrm{d}}(\mathrm{t})<\mathrm{V}_{\mathrm{cd}}(\mathrm{t}) \text {, then } \mathrm{S}_{\mathrm{W}}=1 \text { else } \mathrm{S}_{\mathrm{W}}=0
$$

Where $\mathrm{S}_{\mathrm{W}}$ indicates the switching signals such as 0 and 1 for MOSFET switch OFF and ON respectively.

\subsection{Fuzzy Logic Controller}

The structure of Fuzzy Logic Controller is shown in Figure 7 (a), consists of four stages, namely Fuzzification, knowledge base, fuzzy inference mechanisms and Defuzzification.

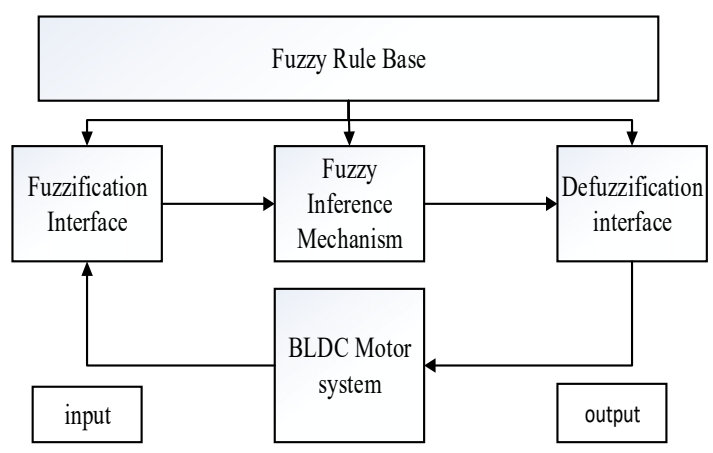

(a)

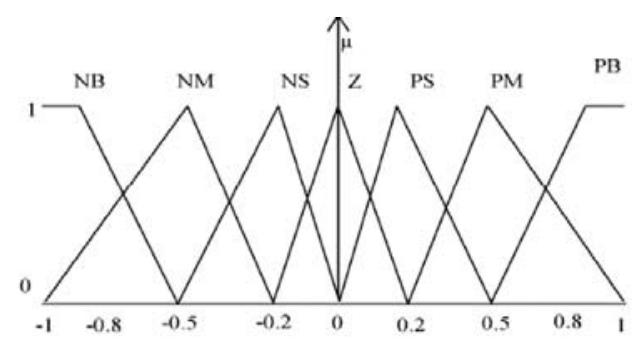

(b)

Figure 7. (a) Shows the structure of fuzzy logic controllers; (b) Membership functions for PWM

The knowledge base comprising a data base and a rule base is designed to attain good dynamic responses under uncertain conditions. The data base contains of input and output membership functions and gives information for suitable Fuzzification, the inference mechanism and Defuzzification operations. The inference mechanism converts the input conditions into a fuzzified output by using a collection of linguistic rules. Lastly, Defuzzification converts the fuzzy outputs. Membership function of FLC is context dependent

\begin{tabular}{|c|c|c|c|c|c|c|c|}
\hline \multirow{2}{*}{ Change In Error } & \multicolumn{7}{|c|}{ Error } \\
\hline & NB & NM & NS & $\mathrm{Z}$ & PS & PM & PB \\
\hline NB & PB & PB & PB & $\overline{\mathrm{PM}}$ & $\mathrm{PM}$ & PS & $\mathrm{Z}$ \\
\hline NM & PB & PB & PM & PM & PS & $\mathrm{Z}$ & Z \\
\hline NS & PB & PM & PS & PS & $\mathrm{Z}$ & NM & NB \\
\hline $\mathrm{Z}$ & PB & PM & PS & Z & NS & NM & NB \\
\hline PS & $\mathrm{PM}$ & PS & Z & NS & NM & NB & NB \\
\hline PM & PS & Z & NS & NM & NM & NB & NB \\
\hline PB & $\mathrm{Z}$ & NS & NM & NM & NB & NB & NB \\
\hline
\end{tabular}
and its membership function is chosen arbitrarily by experience, in this work Gaussian type is preferred.

Table 1. Fuzzy rule based matrix

Int J Pow Elec \& Dri Syst Vol. 10, No. 4, Dec 2019 : $1894-1905$ 
Equation for membership function in Gaussian is

$$
M F=\left\{e^{-\frac{1}{2}}\left(\frac{x-c}{\sigma}\right)^{2}\right\}
$$

For defuzzyfication centroide of gravity $(\mathrm{COG})$ is mainly preffered, $\mathrm{COG}$ governing equation is given below

$$
\mu_{v}=\frac{\int_{v} \mu_{v}(v) v d v}{\int_{v} \mu_{v}(v) d v}
$$

$\mu_{\mathrm{o}}$ is the control output signal given by COG Defuzzification method.

In Fuzzy controller algorithm the optimum value of fuzzy gain $(\mathrm{K})$ is measured by fuzzy inference system which receives as inputs the slope of D.C. average bus voltage and D.C. voltage error. Both quantities (error and slope of DC voltage) are normalized by suitable values. Thus, each range is from -1 to 1 and normalized to unity. The K's value is considered to be near unity. The fuzzy rules shown in table 1 are used to maintain $\mathrm{K}$ gain's value to be near unity. To characterize this fuzzy controller, five sets each respective to the error and slope inputs are chosen. The output is defined by five sets. The error ' $\mathrm{e}$ ' and the change of error 'ce' are used as numerical variables from the real system shown in Figure 7(b). To convert these numerical variables into linguistic variables, the following five fuzzy sets are used: NB (negative big), NS (negative small), ZE (zero), PS (positive small) and PB (positive big).

\section{SIMULATION RESULTS}

The performance of Cuk converter is valued using Matlab/Simulink software in four various modes of operation, based on dissimilar performance parameters. The four modes are Continuous Conduction Mode (CCM), Discontinuous Inductor Current Mode (DICM $\left(\mathrm{L}_{1}\right)$ ), Discontinuous Inductor Current Mode (DICM $\left(\mathrm{L}_{2}\right)$ ), and Discontinuous Capacitor Voltage Mode (DCVM). The overall system's power quality is estimated by the parameters: supply current $\left(i_{s}\right)$ and supply voltage $\left(V_{s}\right)$. The BLDC motor's operation is determined by the stator current $\left(\mathrm{i}_{\mathrm{a}}\right)$, the speed $(\mathrm{N})$ and the electromagnetic torque $\left(\mathrm{T}_{\mathrm{e}}\right)$ of the motor. The performance of the PFC Cuk converter is evaluated by the parameters such as inductor's input and output currents $\left(\mathrm{I}_{\mathrm{L} 1}\right.$ and $\mathrm{I}_{\mathrm{L} 2}$ respectively), intermediate capacitor voltage $\left(\mathrm{V}_{\mathrm{C}}\right)$, DC link voltage $\left(\mathrm{V}_{\mathrm{dc}}\right)$ and switch voltage and current $\left(\mathrm{V}_{\mathrm{SW}}\right.$ and $\mathrm{i}_{\mathrm{sw}}$ ) respectively. The performance of Cuk converter fed BLDC motor has been analyzed for four different modes of operation using fuzzy logic controller. The stress on Cuk converter switch is very low when its operating in CCM modes, but in this mode current multiplier approach is utilized for PFC operation. Current multiplier approach required three sensors, which is not suggested for low coast and low power applications. Table 2 shows that all the parameters for various modes operation of the Cuk converter.

Table 2. Design parameters of cuk converter in different modes of operation

\begin{tabular}{crrrc}
\hline Operation & $L_{i}$ & $L_{o}$ & $C_{1}$ & $C_{d}$ \\
\hline$C C M$ & $2.5 \mathrm{mH}$ & $4.3 \mathrm{mH}$ & $0.66 \mu \mathrm{F}$ & $2200 \mu \mathrm{F}$ \\
$D I C M\left(L_{i}\right)$ & $100 \mu \mathrm{H}$ & $4.3 \mathrm{mH}$ & $0.66 \mu \mathrm{F}$ & $2200 \mu \mathrm{F}$ \\
$\operatorname{DICM}\left(L_{o}\right)$ & $2.5 \mathrm{mH}$ & $70 \mu \mathrm{H}$ & $0.66 \mu \mathrm{F}$ & $2200 \mu \mathrm{F}$ \\
$D C V M\left(C_{1}\right)$ & $2.5 \mathrm{mH}$ & $4.3 \mathrm{mH}$ & $9.1 \mathrm{nF}$ & $2200 \mu \mathrm{F}$ \\
\hline
\end{tabular}

Power quality performance is obtained satisfactory for all the modes of operation. Figure 11 shows THD and power factor variation by the variation of DC link voltage. Figure 12 shows peak voltage and current stress of switch at different loading conditions. The THD of supply current is under acceptable limit of IEC 61000-3-2. The power factor is also near to unity in all modes which shows a unity power factor operation at the $\mathrm{AC}$ mains. 


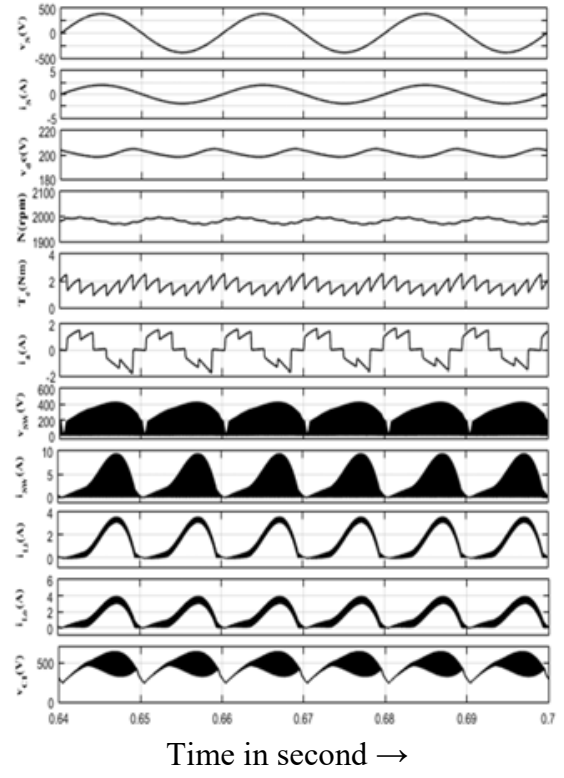

(a)

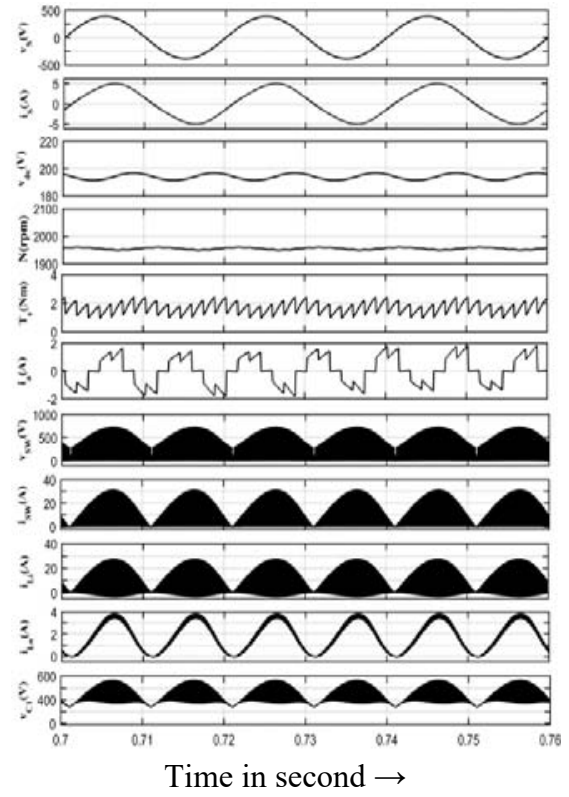

(b)

Figure 9. Steady state performance of motor drive operating in (a) CCM mode, (b) DICM ( $\left.\mathrm{L}_{1}\right)$ mode

An analysis is done on the current stress through the switch and peak voltage across the switch with the variation of load on BLDC motor. Where the voltage stress for DCVM and peak current stress for DICM $\left(\mathrm{L}_{1}\right)$ is very high that cannot be recommended because of higher rated switch requirements. The proposed scheme uses a fundamental switching frequency for VSI operation i.e the losses in voltage source inverter are significantly reduced.

The quality of power at AC mains is determined by the indices of the power quality, Crest Factor (CF), Displacement Power Factor (DPF), Power Factor (PF) and THD (Total Harmonic Distortion) of supply current. Figure 9 and Figure 10 show the steady state performance of Cuk converter fed BLDC motor drive operating in different modes of operation. Table 5 shows the performance of proposed BLDC motor fed Cuk converter operating in CCM, DICM $\left(\mathrm{L}_{1}\right)$, DICM $\left(\mathrm{L}_{2}\right)$ and DCVM modes respectively.

Figure 13 shows the percentage of harmonic current for different order of harmonic and losses of proposed motor drive as comparison of conventional motor drive.Table 4 shows the comparative simulated results of classical and modern control approach in terms of different power quality indices.

Table.3. Specification of BLDC motor

\begin{tabular}{ccc}
\hline S.NO & Parameters & Value \\
\hline 1. & No. of Poles $(\mathrm{P})$ & 4 Poles \\
2. & Rated Power $\left(\mathrm{P}_{\text {rated }}\right)$ & $251.32 \mathrm{~W}$ \\
3. & Rated DC link Voltage $\left(\mathrm{V}_{\text {rated }}\right)$ & $200 \mathrm{~V}$ \\
4. & Rated Torque $\left(\mathrm{T}_{\text {rated }}\right)$ & $1.2 \mathrm{Nm}$ \\
5. & Rated Speed $\left(\omega_{\text {rated }}\right)$ & $2000 \mathrm{rpm}$ \\
6. & Back EMF Constant $\left(\mathrm{K}_{\mathrm{b}}\right)$ & $78 \mathrm{~V} / \mathrm{krpm}$ \\
7. & Torque Constant $\left(\mathrm{K}_{\mathrm{t}}\right)$ & $0.74 \mathrm{Nm} / \mathrm{A}$ \\
8. & Phase Resistance $\left(\mathrm{R}_{\mathrm{ph}}\right)$ & $14.56 \Omega$ \\
9. & Phase Inductance $\left(\mathrm{L}_{\mathrm{ph}}\right)$ & $25.71 \mathrm{mH}$ \\
10. & Moment of Inertia $(\mathrm{J})$ & $1.3^{\times} 10-4 \mathrm{Nm} / \mathrm{s}$ \\
\hline
\end{tabular}

Table 4. Simulation results comparisons

\begin{tabular}{llllll}
\hline Controllers & PF & THD (\%) & CF & Torque Ripple (\%) & Speed Ripple (\%) \\
\hline PI & 0.999 & 6.43 & 1.411 & 33.3 & 0.5 \\
Fuzzy & 0.998 & 4.87 & 1.413 & 25 & 0.1 \\
\hline
\end{tabular}




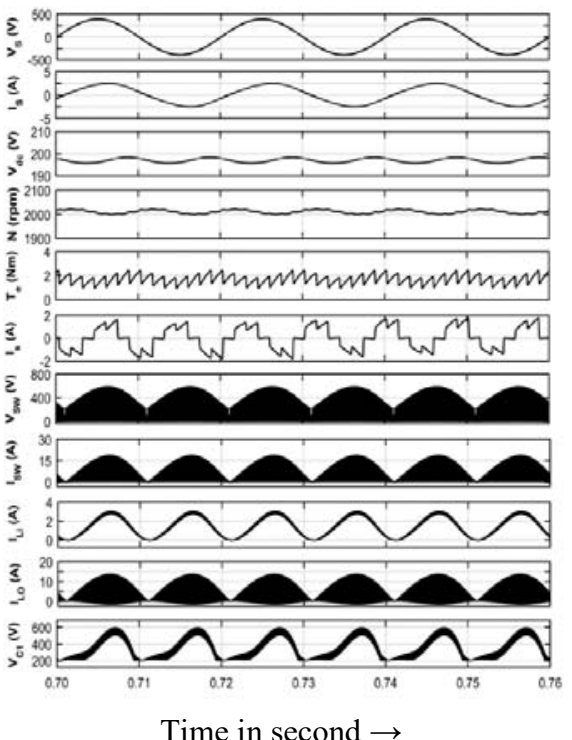

(a)

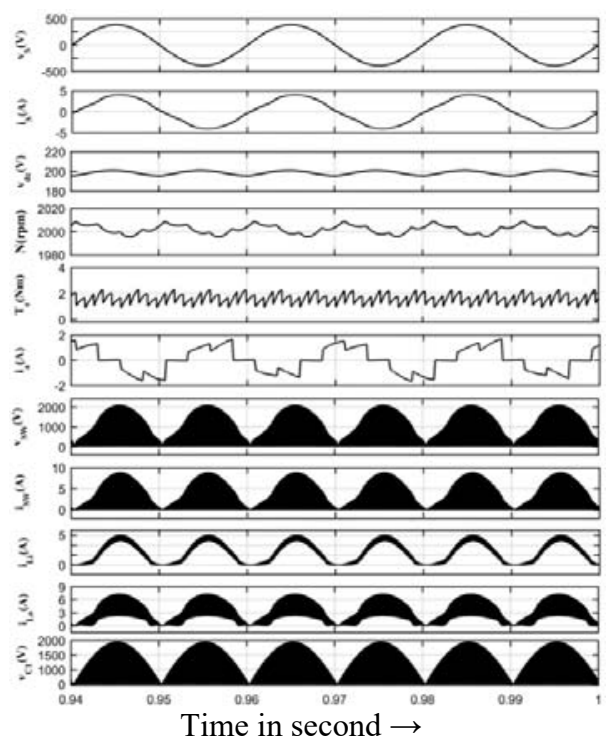

(b)

Figure 10. Steady state performance of motor drive operating in (a) DICM (L1) mode (b) DCVM mode

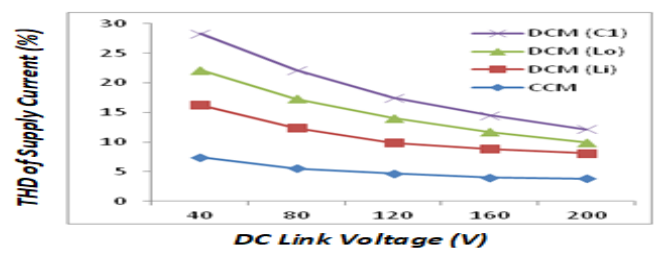

(a)

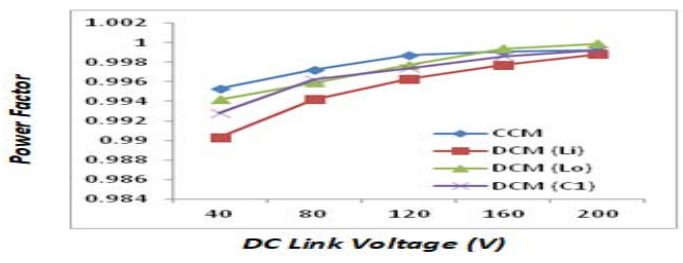

(b)

Figure 11. Performance analysis of (a) \%THD of supply current, (b) Power factor, for different modes of Cuk converter fed BLDC motor drive

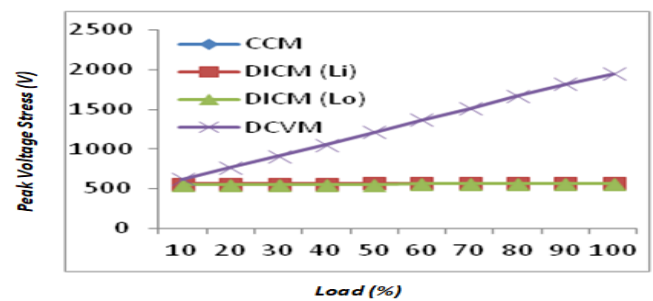

(a)

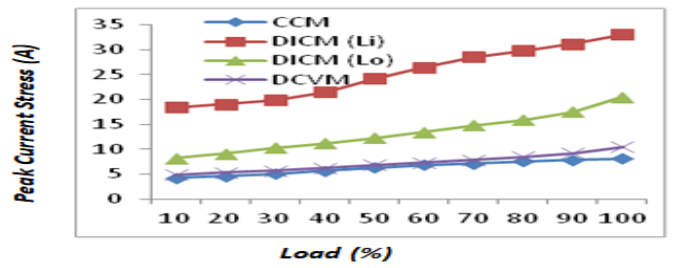

(b)

Figure 12. Performance analysis of (a) Switch peak voltage stress, (b) Switch peak current stress for different modes of Cuk converter fed BLDC motor drive

The losses in a BLDC motor drive are the combination of losses occurs in VSI, PFC converter and BLDC motor. These losses are measured in three different parts of propose drive seperately. 


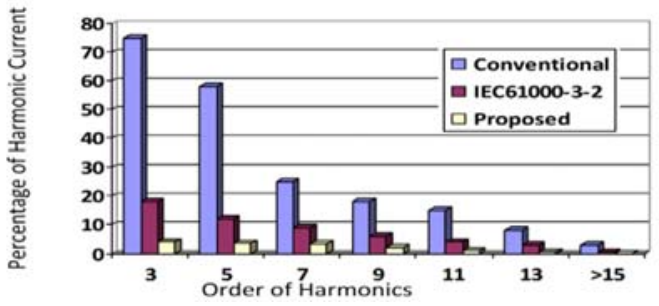

(a)

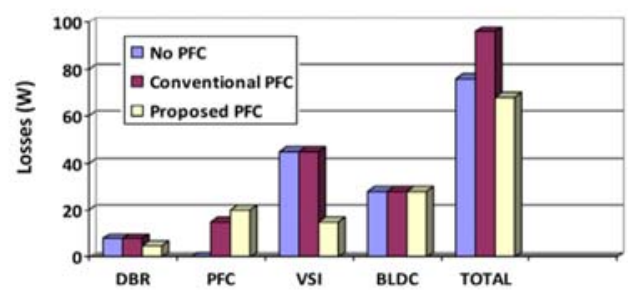

(b)

Figure 13. Comparative Analysis of (a) percentage of harmonic current, (b) losses of proposed Cuk converter fed BLDC motor drive

Table.5. Performance of Cuk Converter fed BLDC Motor Drive

\begin{tabular}{|c|c|c|c|c|c|c|c|c|c|c|c|c|c|}
\hline \multirow[b]{2}{*}{$V_{d c}$} & \multirow[b]{2}{*}{ speed } & \multicolumn{3}{|c|}{ CCM } & \multicolumn{3}{|c|}{$\operatorname{DICM}\left(L_{1}\right)$} & \multicolumn{3}{|c|}{$\operatorname{DICM}\left(\mathrm{L}_{2}\right)$} & \multicolumn{3}{|c|}{$D C V M$} \\
\hline & & $\begin{array}{c}\text { THD of } \\
i_{s}(\%)\end{array}$ & $P F$ & $i_{s}(A)$ & $\begin{array}{c}\text { THD of } \\
i_{s}(\%)\end{array}$ & $P F$ & $i_{s}(A)$ & $\begin{array}{c}\text { THD of } \\
i_{s}(\%)\end{array}$ & $P F$ & $i_{s}(A)$ & $\begin{array}{c}\text { THD of } \\
i_{s}(\%)\end{array}$ & $P F$ & $i_{s}(A)$ \\
\hline 40 & 320 & 7.52 & 0.9941 & 0.453 & 8.96 & 0.9938 & 0.445 & 6.08 & 0.9934 & 0.438 & 6.42 & 0.9915 & 0.465 \\
\hline 80 & 740 & 5.61 & 0.9964 & 0.725 & 7.05 & 0.9957 & 0.723 & 5.21 & 0.9942 & 0.713 & 5.10 & 0.9951 & 0.713 \\
\hline 120 & 1150 & 4.83 & 0.9976 & 0.934 & 5.46 & 0.9973 & 0.989 & 4.28 & 0.9967 & 0.982 & 4.01 & 0.9969 & 1.082 \\
\hline 160 & 1560 & 4.17 & 0.9989 & 1.216 & 4.98 & 0.9981 & 1.289 & 3.08 & 0.9988 & 1.248 & 3.12 & 0.9981 & 1.308 \\
\hline 200 & 1980 & 3.92 & 0.9990 & 1.505 & 4.34 & 0.9992 & 1.597 & 1.99 & 0.9991 & 1.517 & 2.65 & 0.9990 & 1.527 \\
\hline
\end{tabular}

\section{CONCLUSION}

In this paper, a BLDC motor drive fed by a Cuk converter which is power factor corrected was presented. A VSI followed by Cuk converter was used for regulating the speediness of the BLDC motor by changing the DC bus voltage using low frequency switching thus switching losses are reduced. A DBR maintained the unity PF near AC mains by regulating the DC link voltage. The Cuk converter was operated in four different modes of continuous and discontinuous conduction CCM and DCM, for the development of BLDC motor with unity PF at AC mains. Fuzzy Logic Controller is used to enhance the performance of PFC converter, Comparative simulation result are obtained between classical and modern control technique. The simulation of the entire system was done in Matlab/Simulink background and the simulation results evaluated the performance of the proposed system.

\section{ACKNOWLEDGEMENTS}

The proposed research work has been undergone in the electrical engineering department, NIT Jamshedpur. The authors are obliged to Dr. Madhu Singh for continuous guidance throughout the research work.

\section{REFERENCES}

[1] B. Singh and S. Singh, "Single-phase power factor controller topologies for permanent magnet brushless DC motor drives," IET Power Elect., vol. 3, no. 2, pp. 147-175, March 2010.

[2] M. A. Rahman and P. Zhou, "Analysis of brushless permanent magnet synchronous motors," IEEE Trans. Ind. Elect., vol. 43, No. 2, pp. 256-267, Apr 1996.

[3] P. Pillay and R. Krishnan, "Modeling of permanent magnet motor drives," IEEE Trans. Ind. Elect., vol. 35, No. 4, pp. 537-541, Nov 1988.

[4] Lu, D. D. C., Iu, H. H. C., and Pjevalica, V., "Single-Stage AC/DC Boost-Forward Converter with High Power Factor and Regulated Bus and Output Voltages," IEEE Transactions on Industrial Electronics, vol. 56(6), pp. 2128-2132, 2009.

[5] Y. Chen, C. Chiu, Y. Jhang, Z. Tang, and R. Liang, "A Driver for the Single-Phase Brushless DC Fan Motor with Hybrid Winding Structure,” IEEE Trans. Ind. Elect., vol. 60, No. 10, pp. 4369-4375, Oct. 2013.

[6] Chang Liang Xia, Permanent Magnet BLDC Motor Drives and Controls. Wiley Press, Beijing, 2012.

[7] Hamid A. Toliyat and Steven Campbell, DSP-based Electro-mechanical Motion Control. New York, 2004.

[8] N. Mohan, T. M. Undeland and W. P. Robbins, Power Electronics: Converters, Applications and Design. John Wiley and Sons Inc, USA, 2003.

[9] B. Singh, B. N. Singh, A. Chandra, K. Al-Haddad, A. Pandey, and D.P. Kothari, "A review of single-phase improved power quality AC-DC converters," IEEE Trans. Ind. Elect., vol. 50, No. 5, pp. 962-981, Oct. 2003. 
[10] V. Bist and B. Singh, "An Adjustable Speed PFC Bridgeless Buck-Boost Converter Fed BLDC Motor Drive," IEEE Tran. Ind. Electron., vol. 61, no. 6, pp. 2665-2677, June 2014.

[11] V. Bist and B. Singh, "PFC Cuk Converter fed BLDC Motor Drive," IEEE Tran. Ind. Electron., vol. 61, No. 6, pp. 2342-2354, Feb 2014.

[12] S. Kumar and M. Singh, "Improved Power Quality Cuk Converter for Variable Speed BLDC Motor Drive," Journal of Engineering and Applied Sciences, vol. 13, No. 5, pp. 1275-1285, 2018.

[13] D. Roy, M. Singh, and T. Roy, "A Novel Approach for Space Vector Bsed PWM Algorithm for Diode Clamped Three Level VSI fed Iduction Motor Drive," International Journal of Power Electronics and Drive Systems, vol. 8, No. 4, pp. 1534-1547, Dec. 2017.

[14] M. Singh and A. Garg, "Performance Evaluation of BLDC motor with Conventional PI and Fuzzy Speed Controller," IEEE 5th India International Conference on Power Electronics (IICPE), 2012, pp. 1-6, Dec 2012.

[15] R. Arulmozhiyal and R. Kandiban, "Design of Fuzzy PID Controller for Brushless DC motor," IEEE International Conference on Computer Communication and Informatics (ICCCI), 2012, pp. 1-7, June 2018. 